\title{
Analisis Pengaruh Retribusi Rumah Potong Hewan Terhadap Pendapatan Asli Daerah Kota Jambi
}

\author{
Nuraini dan Isnain Effendi \\ Dosen Fakultas Ekonomi Universitas Batanghari Jambi \\ Dosen Fakultas Ekonomi Universitas Muhammadiyah Jambi \\ Correspondence email: nurainilatief@gmail.com \\ Email: isnaineffendi@gmail.com
}

\begin{abstract}
The purpose of the study was to find out and analyze the immense influence of Slaughterhouse Retribution into Original Local Government Revenue. The research object is done in Slaughterhouse Jambi City. The data used in this study is secondary data, this research is a quantitative descriptive that can answer 3 formulation of the problem. The results of the research show, namely: 1). The average growth period 2008-2018 PAD in Jambi City is 22.68 percent, the average during the period of 20082018 growth rate of regional levy in Jambi city increased by 18.78 percent. Average-period of growth $2008-2018$ the reception of Slaughterhouse in the city of Jambi is 52.710 percent. 2). Average in the period 2008-2018 the contribution of the animal home retribution to the city of PAD Jambi is 0.23 percent and the contribution of animal levy to local retribution is 0.67 percent. 3 ). The approximate outcome of a simple linear regression model exposes a positive regression coefficient of $\boldsymbol{Y}=5,595+0,653 \mathrm{X}$. This suggests, every 1 percent increase in the levy of slaughterhouses in Jambi City, PAD will increase by 0,653 percent, and Variations in the ups and downs of the acceptance PAD in Jambi City can be explained by the reception of Animal Home retribution 30.4 percent, while the remaining 69.6 percent are explained by other variables that are not included in this study model.
\end{abstract}

Keywords: Slaughterhouse Retribution, Original Local Government Revenue, Economic Province of Jambi.

\section{PENDAHULUAN}

Pembangunan daerah merupakan bagian integral dari pembangunan nasional, karena itu harus dilaksanakan secara konsisten dan berkesinambungan dalam rangka mendukung dan memperkokoh pembangunan nasional yang bermuara pada peningkatan pendapatan perkapita masyarakat dan memperluas kesempatan kerja. Pembangunan daerah juga merupakan cerminan dari keinginan daerah untuk lebih mampu menjelaskan diri dengan daerah daerah lain yang sudah maju. Kondisi ini secara implicit juga menggambarkan adanya perbedaan tingkat keberhasilah pembangunan antar daerah disebabkan adanya kesenjangan dan kemampuan daerah dalam memanfaatkan dan mengembangkan potensi yang dimilikinya. Perbedaan kemampuan daerah dalam menggali dan memanfaatkan potensi sumberdaya menyebabkan kesulitan dalam penyediaan dana bagi pembiayaan pembangunannya. Kurangnya kemampuan daerah dalam menyediakan dana bagi pembaiayaan pembangunan akan membawa konsekuensi pada kegaitan pembangunan. Perbedaan kemampuan daerah dalam pelaksanaan kegiatan pembangunan akan membawa dampak terciptanya disparitas antar daerah, terutama antar daerah yang kaya dengan daerah yang miskin sumberdaya alam. Dalam rangka mengurangi kesenjangan ( disparitas) pembangunan antar daerah, maka daerah harus diberi keleluasaan untuk menggali dan memanfaatkan potensi yang dimiliki oleh masingmasing daerah, agar memberikan dampak positif terutama bagi tersedianya dana pembiayaan pembangunan.

Diberlakukannya undang-undang nomor 23 tahun 2014 yang merupakan penyempurnaan undangundang 22 tahun 1999 dan undang-undang nomor 32 tahun 2004 tentang pemerintah daerah, telah memberikan kesempatan yang lebih luas bagi daerah untuk mengatur dan mengurus daerahnya sendiri sesuai dengan potensi yang dimiliki. Pemberian otonomi yang lebih luas ini diharapkan akan semakin merangsang pembangunan dan pengembangan potensi yang ada dimasing-masing daerah. Karenanya, untuk mampu membangun dan mengembangkan potensi yang ada tersebut sangat terkait erat dengan sumbersumber pembiayaan pembangunan daerha. Sejalan dengan hal ini maka diterbitkan undang-undangnomor 33 tahun 2004 tentang perimbangan keuangan antara pemerintah pusat dan daerah telah berusaha memberikan peluang yang lebih besar kepada daerah otonomi untuk mencari dan mengembangjan sumber-sumber peneriamaan daerah, sebagai sumber pembiayaan pembangunan daerah. Untuk menentukan besarnya biaya pembangunan tersebut, maka diperlukan kebijaksanaan pemerintah untuk mencari sumber-sumber penerimaan keuangan daerah, diantaranya smenyangkut pendapatan asli daerah (PAD). Peningkatan pendapatan asli daerah (PAD) ini dimaksudkan untuk mengurangi ketergantungan kepada pemerintah pusat. 
Peningkatan sumber pembiayaan pembangunan bagi pemerintah daerah dilakukan melalui berbagai usaha peningkatan pendapatan asli daerah, melalui usaha mendorong peningkatan ekonomi dan peran sosial masyarakat terutama yang berkaitan dengan usaha-usaha peningkatan pendapatan asli daerah.

Salah satu komponen penerimaan PAD berasal dari retribusi daerah. Retribusi daerah memegang peranan penting dalam pembentukan PAD kota Jambi. Perkembangan PAD Kota Jambi sendiri terus mengalami peningkatan siring dengan peningkatan komponen pembentuknya. Mengingat retribusi daerah merupakan komponen penting dari PAD maka sudah sewajarnya apabila potensi yang berasal dari retribusi daerah ini digali. Salah satu komponen pembentuk PAD retribusi rumah potong hewan, sebagai komponen pembentuk PAD retribusi potong hewan harus terus diupayakan peningkatannya dari waktu kewaktu guna mendukung peningkatan PAD. Adapun perkembangan penerimaan retribusi rumah potong hewan dapat dilihat pada table berikut ini :

Tabel 1

Target dan realisasi penerimaan retribusi rumah potong hewan kota Jambi 2008 - 2018

\begin{tabular}{cccc}
\hline Tahun & Target $(\mathbf{R p )}$ & Realisasi (Rp) & Pendapaian Relisasi (\%) \\
\hline 2008 & $120,000,000$ & $147,499,000$ & 122.91 \\
2009 & $125,000,000$ & $175,485,000$ & 140.39 \\
2010 & $130,000,000$ & $175,266,000$ & 134.82 \\
2011 & $135,000,000$ & $149,419,000$ & 110.68 \\
2012 & $137,000,000$ & $122,419,000$ & 89.36 \\
2013 & $140,000,000$ & $134,535,000$ & 96.09 \\
2014 & $140,000,000$ & $131,396,000$ & 93.85 \\
2015 & $190,000,000$ & $187,614,000$ & 98.74 \\
2016 & $200,000,000$ & $187,614,000$ & 93.81 \\
2017 & $240,000,000$ & $201,745,000$ & 84.06 \\
2018 & $500,000,000$ & $1,176,326,000$ & 235.26 \\
& Rata - Rata & & 118.18 \\
\hline
\end{tabular}

Sumber : BPS Kota Jambi tahun 2019

Tabel 1 diatas terlihat bahwa selam periode 2008 - 2018 realisasi penerimaan retribusi rumah potong hewan di kota Jambi secara rata-rata adalah sebesar 118,17, sementara penerimaan retribusi rumah potong hewan menunjukkan kecenderungan yang terus meningkat dari tahun ketahun. Retribusi potong hewan mempunyai potensi yang besar untuk dikembangkan lebih lanjut sebagai salah satu sumber retribusi yang memiliki prospek positif. Retribusi ini berpotensi besar mengingat dari sapi dan kerbau menunjukkan peningkatan. Peningkatan ini jelas membawa konsekuensi dengan meningkatnya jumlah hewan yang dipotong, sehingga mendorong peningkatan penerimaan retribusi rumah potong hewan di kota Jambi.

Hal ini jelas mempunyai potensi yang besar apabila mampu dikelola secara optimal. Mengingat retribusi potong hewan ini biasanya dipungut di rumah pemotongan hewan (RPH) dan juga ada yang di luar RPH. Potensi yang besar ini akan dapat di optimalkan apabila diketahui potensi yang sebenarnya. Adapun tujuan penelitian ini adalah untuk megetahui pengaruh retribusi rumah potong hewan terhadap pendapatang asli daerah di kota Jambi

\section{METODE}

Adapun metode penelitian yang digunakan dalam penelitian ini adalah metode analisis data sekunder. Menurut singarimbun (2001) yang dimaksud dengan analisis data sekunder adalah analisa yang dilakukan terhadap data yang dikumpulkan oleh instansi lain terlebih dahulu. Sumber dan jenis data yang digunakan dalam penelitian ini adalah data sekunder. Data sekunder yang dibutuhkan meliputi jumlah penerimaan wajib pajak daerah, retribusi rumah potong hewan dan PAD Kota Jambi menurut komponen penerimaan. Dimana semua data-data tersebut diperoleh dari laporan berbagai instansi yang antara lain : Badan pengelolaan pajak dan retribusi daerah kota Jambi, Bappeda kota Jambi, Kantor BPS kota Jambi dan Instansi terkait lainnya

Disamping itu dilakukan penelitian kepustakaan untuk memperoleh data dan informasi yang dapat dipertanggung jawabkan untuk mendukung perumusan masalah. Untuk menjawab tujuan penelitian yang pertama digunakan metode analisis deskriftif. Metode analisis ini digunakan untuk melihat gambaran secara 
sistematis dan factual mengenai keadaan yang diteliti. Sedangkan untuk mengetahui perkembangan penerimaan retribusi rumah potong hewan digunakan rumus sebagai berikut : (dajan, 2005).

$\mathrm{Gn}=\frac{(P a-P o)}{P_{0}} \times 100$

Dimana : Gn : perkembangan penerimaan retribusi rumah potong hewan tahun ke-n; Pa : data tahun ke-n

$\mathrm{P0}:$ data tahun awal

$\mathrm{K}=\frac{(\mathrm{Vxn})}{(\mathrm{Van})} \times 100 \%$

Dimana : K : persentase kontribusi retribusi rumah potong hewan di kota Jambi; Vxn : jumlah penerimaan retribusi rumah potong hewan di kota Jambi; Vzn : jumlah penerimaan retribusi daerah / PAD kota Jambi

Untuk menjawab permasalhan ketiga yaitu mengetahui pengaruh retribusi rumah potong hewan terhadap pendapatan asli daerah digunakan analisis regresi linier sederhana yaitu :

$\mathrm{Y}=\beta 0+\beta 1 \mathrm{X} 1$

Dimana : Y : pendapatan asli daerah; X1 : retribusi rumah potong hewan; $\beta 0$ : bilangan konstan (Tetap); $\beta 1$ : koefisien retribusi rumah potong hewan

\section{Uji $t$}

Untuk menguji apakah secara individu masing - masing variable independent berpengaruh secara Signifikan. Dengan menggunakan rumus :

$\mathrm{t}($ hitung $)=\frac{B 1}{\operatorname{Se}(B i)}$

Dimana : $\mathrm{t}$ (hitung) : koefisien regresi hasil estimasi; $S e(\beta i)$ : simpangan baku koefisien regresi

Kriteria pengujian, bila nilai t hitung yang diperoleh lebih besar atau sama dengan $t$ table maka hipotesa nol ditolak,. Berarti variable independent mempunyai pengaruh yang signifikan terhadap variable dependent, bila t hitung lebih kecil dari t table maka hipotesa nol diterima dan hipotesa alternative ditolak, ini berarti tidak ada pengaruh variable independent secara parsial terhadap variable pada tingkat keyakinan tertentu.

Opersional variable

Adapun variable dalam penelitian ini adalah sebagai berikut :

1. Retribusi rumah potong hewan adalah penerimaan retribusi yang berasal dari aktivitas pemotongan hewan di rumahpotonghewan kota Jambi yang dihitung dalam satuan Rupiah per tahun.

2. Retribusi daerah adalah penerimaan daerah yang berasal dari jenis retribusi daerah yang diatur dalam peraturan di kota Jambi yang dihitung dalam satuan Rupiah pertahun

3. Pendapatan asli daerah adalah penerimaan daerah yang berasal dari potensi daerah yang diatur dalam peraturan di kota Jambi yang dihitung dalam satuan Rupaiah Pertahun.

\section{HASIL}

\section{Perkembangan penerimaan retribusi rumah potong hewan di kota Jambi}

Retribusi rumah potong hewan adalah jenis pungutan yang dilakukans pemerintah terhadap objek pajak, dalam hal ini adalah kegiatan dari aktivitas pemotongan hewan dari rumah potong hewan di kota jambi yang dipungut biaya dengan besaran yang sudah di tentukan. Selama periode $2008-2018$ penerimaan retribusi rumah pototng hewan di kota Jambi menunjukkan kecenderungan yang terus meningkat sebagaimana terlihat di table berikut :

Tabel 2

Perkembangan penerimaan retribusi rumah pototng hewan kota Jambi periode 2008 - 2018

\begin{tabular}{ccc}
\hline Tahun & Penerimaan RPH $(\mathbf{R p )}$ & Perkembangan $(\%)$ \\
2008 & $147,499,000$ & - \\
2009 & $175,485,000$ & 18.97 \\
2010 & $175,266,000$ & $(19.10)$ \\
2011 & $149,419,000$ & $(14.62)$ \\
2012 & $122,419,000$ & $(3.32)$ \\
2013 & $134,535,000$ & 27.97 \\
2014 & $131,396,000$ & $(12.23)$ \\
2015 & $187,614,000$ & 45.12
\end{tabular}




\begin{tabular}{ccc}
2016 & $187,614,000$ & $(42.79)$ \\
2017 & $201,745,000$ & 7.53 \\
2018 & $1,176,326,000$ & 475.54 \\
& Rata - Rata & 48.31 \\
\hline
\end{tabular}

Sumber : DPKAD kota Jambi tahun 2019

Berdasarkan table diatastergambar bahwa selama periode 2008 - 2018 retribusi rumah potong hewan di kota Jambi menunjukkan kecenderungan yang meningkat, meskipun sempat mengalami penurunan pada beberapa tahu, laju pertumbuhan penerimaan retribusi rumah potong hewan tertinggi selama kurun waktu 2008 -2018 di kota Jambi adalah sebesar 483 persen yang terjadi pada tahun 2018, tingginya laju penerimaan retribusi rumah potong hewan pada tahun ini disebabkan semakin bertambahnya peran rumah potong hewan sebagai tempat resmi pemotongan hewan ternak di kota Jambi dan juga menunjukkan perkembangan kota Jambi. Sementara pertumbuhan terendah terjadi pada tahun 2010, yaitu sebesar minus 18,07 persen.

\section{Kontribusi retribusi rumah potong hewan terhadap PAD dan Retribusi daerah di kota Jambi}

Sebagai sumber penerimaan retribusi rumah potong hewan sangat penting guna mendorong peningkatan penerimaan pajak dan PAD, dengan demikian diharapkan akan menjadi sumber pembiayaan pembangunan daerah kota Jambi. Selam periode 2008 -2018 kontribusi retribusi rumah potong hewan terhadap PAD dan retribusi daerah menunjukkan kecenderungan yang meningkat sebagaimana tergambar pada Tabel berikut :

Tabel 3

Kontribusi retribusi rumah potong hewan terhadap PAD dan Retribusi daerah di kota Jambi tahun 2008 - 2018

\begin{tabular}{|c|c|c|c|c|c|}
\hline Tahun & PAD (Rp.000) & $\begin{array}{l}\text { Retribusi Daerah } \\
\quad(\text { Rp.000) }\end{array}$ & $\begin{array}{l}\text { Retribusi RPH } \\
\quad(\mathrm{Rp} .000)\end{array}$ & $\begin{array}{c}\text { kontribusi RPH } \\
\text { terhadap PAD } \\
(\%)\end{array}$ & $\begin{array}{l}\text { kontribusi RPH } \\
\text { terhadap Retribusi } \\
\text { daerah }(\%)\end{array}$ \\
\hline 2008 & $43,323,300.00$ & $22,665,320.00$ & $147,499.00$ & 0.34 & 0.65 \\
\hline 2009 & $38,091,112.00$ & $23,654,240.00$ & $175,485.00$ & 0.46 & 0.74 \\
\hline 2010 & $54,086,832.00$ & $20,352,022.00$ & $175,266.00$ & 0.32 & 0.86 \\
\hline 2011 & $55,671,282.00$ & $18,308,852.00$ & $149,419.00$ & 0.27 & 0.82 \\
\hline 2012 & $72,597,791.00$ & $32,481,632.00$ & $122,419.00$ & 0.17 & 0.38 \\
\hline 2013 & $97,843,296.00$ & $23,974,353.00$ & $134,535.00$ & 0.14 & 0.56 \\
\hline 2014 & $113,090,049.00$ & $22,936,216.00$ & $131,396.00$ & 0.12 & 0.57 \\
\hline 2015 & $149,041,879.00$ & $30,290,436.00$ & $187,614.00$ & 0.13 & 0.62 \\
\hline 2016 & $246,427,699.00$ & $56,939,980.00$ & $187,614.00$ & 0.08 & 0.33 \\
\hline 2017 & $263,925,522.00$ & $58,812,353.00$ & $201,745.00$ & 0.08 & 0.34 \\
\hline 2018 & $287,564,676.00$ & $80,718,527.00$ & $1,176,326.00$ & 0.41 & 1.46 \\
\hline \multicolumn{4}{|c|}{ Rata - Rata } & \multicolumn{2}{|r|}{0.67} \\
\hline
\end{tabular}

Sumber : Dinas Pendapatan Dan Kekayaan Daerah Kota Jambi, 2019

Berdasarkan table diatas terlihat bahwa selama periode 2008 - 2018 Kontribusi retribusi rumah potong hewan terhadap PAD daerah di kota Jambi terendah terjadi pada tahun 2016 dan 2017, yaitu sebesar 0,08 persen, secara rata - rata selama periode 2008 - 2018 Kontribusi retribusi rumah potong hewan terhadap PAD kota Jambi adalah sebesar 0.23 persen. Meningkatnya kontribusi retribusi rumah potong hewan terhadap PAD diharapkan akan menjadi sumber pembiayaan bagi pembangunan daerah. Kontribusi retribusi rumah potong hewan terhadap Retribusi daerah di kota Jambi juga menunjukkan kecenderungan yang meningkat. Kontribusi retribusi rumah potong hewan terhadap Retribusi daerah di kota Jambi tertinggi terjadi pada tahun 2018 , yaitu sebesar 1,46 persen, laju kontribusi terendah terjadi pada tahun 2016, yaitu sebesar 0,33 persen. Secara rata - rata Kontribusi retribusi rumah potong hewan terhadap Retribusi daerah di kota Jambi adalah sebesar 0,67.

\section{Persamaan regresi}

Berdasarkan hasil pengujian diperoleh persamaan regresi sebagai berikut 
Tabel 4

Nilai nilai koefisien regresi dan nilai-nilai $t$ hitung

\begin{tabular}{|c|c|c|c|c|c|}
\hline \multirow[t]{2}{*}{ Model } & \multicolumn{2}{|c|}{ Unstandardized Coefficients } & \multirow{2}{*}{$\begin{array}{c}\text { Standardized Coefficients } \\
\text { Beta }\end{array}$} & \multirow[t]{2}{*}{$\mathrm{t}$} & \multirow[t]{2}{*}{ Sig. } \\
\hline & $\mathrm{B}$ & Std. Error & & & \\
\hline (Constant) & 5.595 & 2.727 & & 2.052 & .070 \\
\hline Retribusi RPH & .653 & .289 & .552 & 2.260 & .005 \\
\hline
\end{tabular}

Sumber: data olahan

Nilai-nilai koefisien yang terdapat pada tabel persamaan regresi linear sederhana diatas, maka model yang dapat disusun untuk penelitian ini adalah:

$\mathbf{Y}=\mathbf{5 . 5 9 5}+\mathbf{0 . 6 5 3} \mathrm{X}$

Keterangan: $\mathrm{Y}=\mathrm{PAD}$ di Kota Jambi; $\mathrm{X}=$ Retribusi RPH

Berdasarkan persamaan regresi linear sederhana diatas diketahui bahwa koefisien regresi Retribusi RPH bernilai positif. Dengan kata lain variabel Retribusi RPH dapat dijadikan alat untuk memprediksi PAD di kota Jambi. Koefisien variabel Retribusi RPH sebesar 0,653 artinya setiap terjadi kenaikan retribusi Rumah Potong Hewan sebesar 1\% maka mengakibatkan PAD di kota Jambi mengalami kenaikan sebesar 65,3\%. Berdasarkan keterangan diatas diketahui nilai constant sebesar 5,595. Artinya apabila variabel Retribusi RPH dianggap konstan (bernilai 0), maka variabel PAD di Kota Jambi sebesar 5,595.

\section{Uji signifikansi (uji Hipotesis)}

Uji t digunakan untuk melihat apakah secara parsial retribusi retribusi rumah potong hewan terhadap PAD di kota Jambi. Berdasarkan hasil pengujian diperoleh nilai t hitung sebagaimana tergambar pada diatas adalah sebesar 2,260. Artinya secara parsial penerimaan rumah potong hewan berpengaruh secara signifikan terhadap PAD di kota Jambi.

\section{Koefisien Korelasi dan Deteminasi}

Koefisien determinasi dilambangkan dengan nilai $\mathrm{R}^{2}$. Nilai ini menyatakan proporsi variasi keseluruhan dalam nilai dependen yang dapat diterangkan atau diakibatkan oleh hubungan linear dengan variabel independen, selain itu (sisanya) diterangkan oleh variabel lain. Hasil perhitungan SPSS untuk melihat koefisien determinasi dapat dilihat pada model summary berikut ini:

Tabel 5

Koefisien Korelasi dan Determinasi

\begin{tabular}{lllll}
\hline Model & R & R Square & Adjusted R Square & Std. Error of the Estimate \\
\hline 1 & $.552^{\mathrm{a}}$ & .304 & .227 & .28249 \\
\hline
\end{tabular}

Sumber: data olahan

Koefisien korelasi dalam penelitian ini adalah 0,552, artinya terdapat hubungan yang sangat erat antara variabel Retribusi RPH (X) terhadap PAD (Y) di kota Jambi. Dari hasil pengujian SPSS maka diperoleh nilai koefisien determinasi= adjusted $\mathrm{R}$ square sebesar 0,304 angka ini menyatakan bahwa variabel Retribusi RPH (X) mampu menjelaskan variabel PAD di Kota Jambi(Y) sebesar 30,4 \% dan sisanya sebesar $22,7 \%$ dijelaskan oleh faktor-faktor lain yang tidak dimasukkan dalam model penelitian ini.

\section{SIMPULAN} berikut:

Hasil penelitian dan pembahasan seperti yang telah diuraikan, maka dapat disimpulkan sebagai

1. Secara rata - rata selama periode 2008 -2018 laju pertumbuhan PAD di Kota Jambi adalah Sebesar 22,68 persen, secara rata - rata selama periode 2008 - 2018 laju pertumbuhan penerimaan retribusi daerah di kota Jambi mengalami peningkatan sebesar 18,78 persen. Secara rata - rata selama periode 2008 -2018 laju pertumbuhan penerimaan retribusi rumah potong hewan di kota Jambi adalah sebesar 52,710 persen.

2. Secara rata - rata selama periode 2008 -2018 Kontribusi retribusi rumah potong hewan terhadap PAD Kota Jambi adalah sebesar 0,23 persen dan kontribusi retribusi rumah potong hewan terhadap retribusi daerah adalah sebesar 0,67 persen. 
3. Hasil estimasi model regresi linier sederhana memperlihatkan koefisien regresi yang positif yaitu $\mathbf{Y}=$ $5.595+0.653 \mathbf{X}$. Hal ini memperlihatkan, Setiap terjadi peningkatan 1 Persen penerimaan retribusi rumah potong hewan di kota Jambi maka PAD akan mengalami peningkatan sebesar 0.653 persen, dan variasi naik turunnya penerimaan PAD di Kota Jambi mampu dijelaskan oleh penerimaan retribusi rumah potong hewan sebesar 30,4 persen, sementara sisanya sebesar 69,6 persen dijelaskan oleh variable lainnya yang tidak dimasukkan dalam model penelitian ini.

\section{DAFTAR PUSTAKA}

Azis Iwan jaya, Perekonomian Indonesia, BP FE-UI, Jakarta

Amir, A. 2007. Pembangunan Dan Kualitas Pertumbuhan Ekonomi Dalam Era Globalisasi ( Teori, Masalah dan kebijakan ), Edisi Pertama, Jambi

Amir, Junaidi, Yulmardi. 2009. Metodologi Penelitian Ekonomi Dan Penerapannya, IPB Press, Jambi

Anna. Yulianita. Analisis Sekktor Unggulan dan Pengeluaran Pemerintah Di Kabupaten Ogan Komering Ilir. Sumatera Selatan

Anonym. 2014. Undang - undang No. 23 Tahun 2014 Tentang Pemerintrahan Daerah. Undang - undang No. 23 Tahun 201. DEPDAGRI.

2019. Dinas Pendapatan Dan Kekayaan Daerah Kota Jambi, Jambi

2019. Badan pengelolaan pajak dan retribusi daerah kota Jambi, Jambi

2019. BAPPEDA kota Jambi, Jambi

2019. BPS Provinsi Jambi, Jambi

2008 - 2018 . Badan Pusat Statistik. Statistik Indonesia Tahun 2008 -2018, Jakarta

2008 - 2018. Badan Pusat Statistik Provinsi Jambi. Jambi Dalam Angka, Jambi

Bachtiar,N. 2002. Otonomi dan implikasinya terhadap kemampuan keuangan daerah, jurnal ekonomi dan manajemen, vol I, FEUA, Padang

Eko. Wicaksono Pambudi. 2013. Analisis Pertumbuhan Ekonomi dan Faktor - Faktor Yang Mempengaruhi ( Kabupaten / Kota Di Provinsi Jawa Tengah). Semarang

Ghozali. I. 2006. Statistik No Para-Metrik Teori dan Aplikasi Dengan Program Spss. UNDIP. Semarang

Hodijah. Siti. 2015. Pengaruh Pertumbuhan Ekonomi, Investasi, PAD, Terhadap Kemiskinan Melalui Kesempatan Kerja di Provinsi Jambi. Jambi

Kuncoro. Mudrajad. 2015. Indikator Ekonomi, Yogyakarta

Tan, syamsurizal, 2004. Infrastruktur dan industry dalam mempercepat laju pertumbuhan ekonomi Jambi, makalah pada one day open discussion, tidak diterbitkan

Thaniapm, 2016, Tugas Hukum otonomi daerah dan sumber pendapatan asli daerah UU no 23 tahun 2014

Wikiapbn.org, pajak daerah dan retribusi daerah 